\section{Hovedsakelig om nyresvikt}

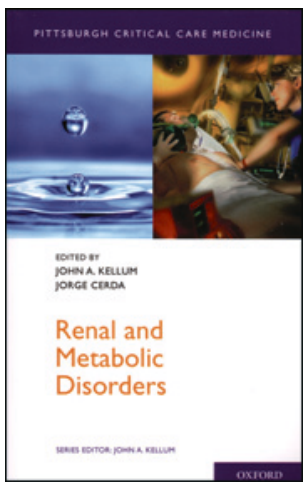

John A. Kellum, Jorge Cerda, red.

Renal and metabolic disorders

222 s, tab, ill. Oxford: Oxford University Press 2013. Pris GBP 40

ISBN 978-0-19-975160-0

Denne boken er del av en serie bøker i lommeformat som kalles Pittsburgh critical care medicine series. Forfatterne er spesialister i intensivmedisin og i nyremedisin. Den er beregnet på studenter og leger som arbeider med intensivmedisinske problemer.

Dette er først og fremst en bok om nyresvikt. Den første delen omfatter 17 korte kapitler som omfatter nyresvikt i ulike kliniske situasjoner. Det er ikke først og fremst tradisjonell dialysetrengende nyresvikt som omtales, men begrepet «acute kidney injury», som er en betegnelse for lettere grader av sviktende nyrefunksjon, vurdert ut fra diurese og kreatininmålinger. Kapitlene er skrevet av ulike forfattere, og det blir derfor en del gjentakelser, særlig av årsakene til «acute kidney injury».

Når det gjelder endokrine og metabolske forstyrrelser, er disse omtalt i de fem siste kapitlene og innbefatter problemer relatert til diabetes og sykdommer i binyre og thyreoidea i akuttmedisinsk praksis. Kalkstoffskiftet og ernæring av intensivpasienter omtales også.

Forfatterne gir en nyttig oppdatering om «acute kidney injury», som er et relativt nytt begrep innen medisin. Boken er kortfattet og ment som et praktisk hjelpemiddel på avdelingen. Dette har forfatterne lyktes med. Teksten er meget konkret og konsis og full av oversiktlige tabeller og spesifikke diagnostiske og terapeutiske tiltak. Den er godt oppdatert med referanser til den nyeste litteraturen. Dessverre er det litt tungvint for norske lesere at man ikke bruker SI-enheter - her angir man blodglukose og elektrolytter i mg/dl etc. Dette medfører at tabellene ikke alltid er så praktiske i bruk som de kunne ha vært. Likevel vil den kunne være en støtte til rask diagnostikk og behandling i ulike situasjoner. Den er imidlertid, som nevnt, beregnet som en praktisk hjelper, og gir ikke dypere innsikt i tilstandene som omtales. Som sådan kan jeg anbefale den som et godt hjelpemiddel for leger og andre spesialister som behandler pasienter med akuttmedisinske tilstander.

\section{Anders Hartmann}

Nyreseksjonen

Klinikk for spesialisert medisin og kirurgi

Oslo universitetssykehus, Rikshospitalet

\section{Nevrologi før eksamen}

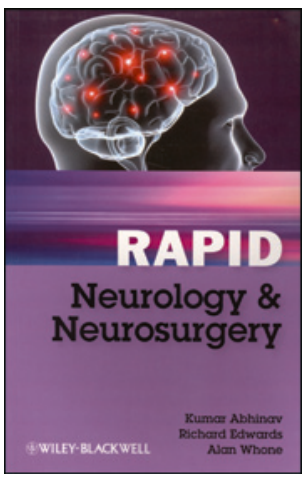

Kumar Abhinav, Richard Edwards,

Alan Whone

Rapid

Neurology and neurosurgery. 188 s, tab, ill.

Chichester: Wiley-Blackwell, 2012.

Pris GBP 20

ISBN 978-0-470-65443-9

I denne kortfattede læreboken presenterer forfatterne nevrologi og nevrokirurgi punktvis. I forordet klargjør de hensikten: å forberede medisinstudenter på eksamen, og ganske særlig på eksamensformer som inkluderer «multiple choice questions» og «objective structured clinical examinations» (OSCE).

I del 1 gir forfatterne en summarisk oversikt over de mest sentrale aspektene av nevroanatomien i et klinisk perspektiv, i tillegg til en oversikt over kliniske og supplerende undersøkelser. I del 2 tar de utgangspunkt i symptomer slik de fremstilles til eksamen, og med en differensialdiagnostisk drøfting. Eksempler er hodepine, svimmelhet og kraftsvikt i bena. I del 3 beskriver de hver enkelt sykdomsgruppe på mer konvensjonelt vis, men fortsatt konsekvent punktvis.

Boken dekker nevrologisk og nevrokirurgisk kjernepensum for medisinstudenter. Den er imidlertid mer et supplement enn selve læreboken i faget. Dens form, med nevrologien i punkter og tabeller, er rettet mot besvarelse av standardiserte eksamensspørsmål. Boken er oppdatert, korrekt og tilstrekkelig utfyllende. Forfatterne har ingen ambisjon om å gi innsikt og forståelse og tar ikke opp behandlingsmessige avveininger, forebygging eller aspekter som gir fundament for fremtidig terapi. Sammensatte og pasientnære eksamensformer er likeledes noe lenger unna det de har satt søkelyset på.

For spesialistkandidater i nevrologi vil boken representere en enkel repetisjon av diagnostiske alternativer med oppskrifter for utredning og behandling. Den egner seg ikke til oppslag når man har en interessant eller vanskelig pasient. Både i primær- og spesialisthelsetjenesten vil andre kunnskapskilder da være vesentlig bedre.

Boken er liten og lett, tettskrevet og i et format beregnet på å tas med i lommen eller vesken, til kollokvier eller på trikken.

Denne boken kan være et supplement for studenter og unge leger før prøver og eksamener. Den kan for eksempel danne et grunnlag for kollokvier og smågruppeundervisning. Imidlertid er den ikke et alternativ som lærebok i nevrologi og nevrokirurgi. Til det er den for knapp, kjapp og punktbasert.

Nils Erik Gilhus

Klinisk institutt 1

Universitetet i Bergen 